\title{
二次元長方形市街地空間の路上にある人体の 熱負荷に関する解析的研究
}

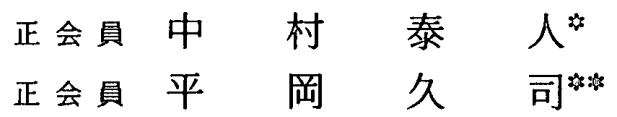

\section{1. 研究目的}

市街地の典型として長方形の市街地キャビティ空間を とりあげ，直接的には地上にある人体に対する熱環境制 御，間接的には建物内部へ作用するものとしての外部熱 環境制御，を目標として，本研究では，二次元長方形キャ ビティ空間の地上での人体熱負荷の計算を行い，キャビ ティの方位，地面材料の違いによる効果について数值解 析により検討する。ここに人体熱負荷とは，一定体温を 保てなくなるほどの過大の熱量が人体に作用することを いい，それを負荷と呼んでいる。

市街地空間内での熱環境形成に関する研究には, T. R. Oke ${ }^{1)-3)}$, W. H. Terjung() - 1)，内藤，水野 ${ }^{8)}$ らの 研究がある。Okeらは市街地空間におけるキャビティ 内での長波長放射 ${ }^{11.2)}$ ，およびエネルギー収支 ${ }^{3)}$ に関して， 実測による研究を行っている。Terjung らは，一般の市 街地空間に対して数值モデルにより，表面温度の形 成 4 .5)および人体に対する熱環境状態6),7)について研究し ている。内藤らは凹凸モデルとして二次元直角キャビ ティを用い，数値計算によって都市気温形成に関し，凹 凸の効果と他の因子のそれを比較している88。

本報では，市街地キャビティ内の人体の熱収支状態に 対し，キャビティ内の気流性 (平均風速) の変化に伴う 人体の熱収支の変化も考慮し, キャビティの方位, 地面 材料の違いが，キャビティ内の人体の熱環境形成にビの ような効果を及ぼすかを数值計算により調べる。

\section{2. 研究方法}

図一1に示す二次元長方形空間を考え，このキャビ ティ空間の地上での人体熱収支計算を行った。計算に用 いた近似に関しては，キャビティ内の気温および湿度の 分布は無視し得るものと見做し，上層の気温および湿度 に等しいとした。この近似の妥当性は地上近辺を除き, 実測により確かめられている9)。人体熱収支計算では地 上近辺もキャビティ内の主部と同一の気温および湿度に 等しいとした。

\footnotetext{
。京都大学 助教授.工博

40 京都大学 助手.工修 (昭和 60 年 10 月 3 日原稿受理)
}

図一 2 に計算のフローチャートを示す。計算に与える 入力は時刻別気象データ（図一5，表一4）である。

計算の手順は,

(1)直達日射量と天空日射量からキャビティ表面に入射

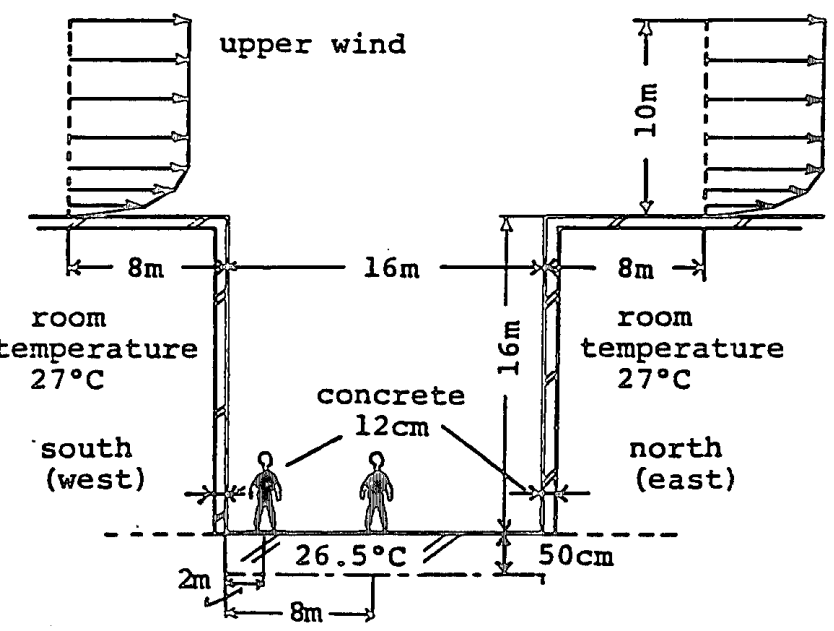

图一1 都市キャビティのモデル

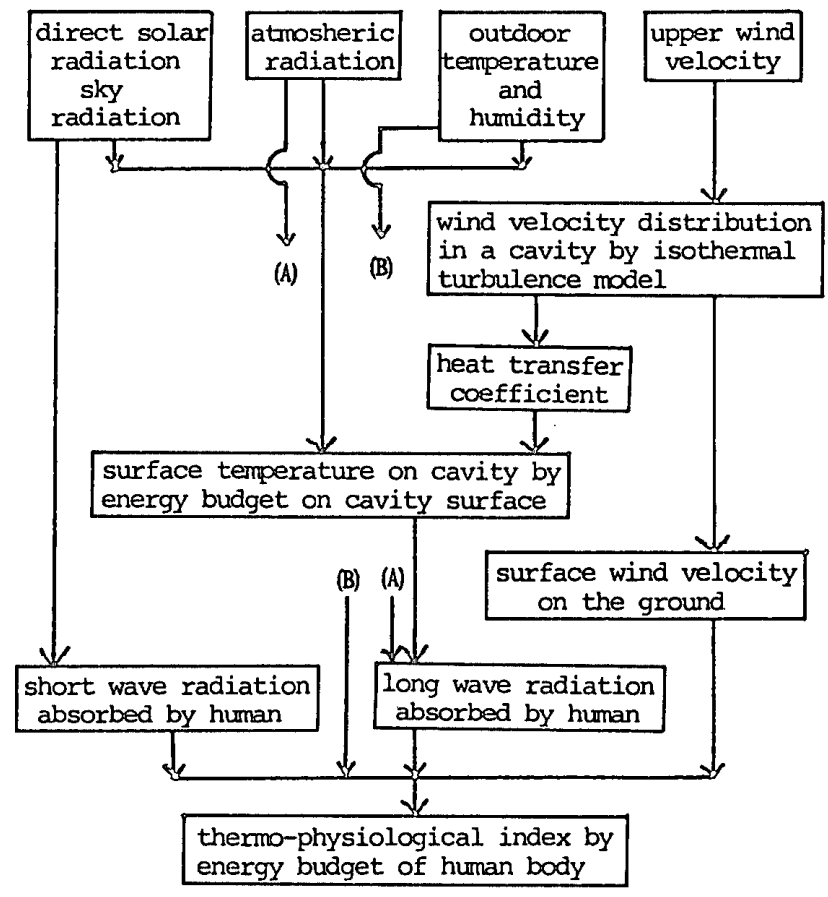

圈一2 フローチャート 
する日射量を計算する。

(2)上層の風向風速からキャビティ内の気流分布とキャ ビティ表面の対流熱伝達率を計算する。

(3)対流熱伝達率, (1)で求めた入射する日射量, および キャビティ内の気温と湿度を既知とし，キャビティ 表面での熱収支式からキャビティ表面温度と長波長 の放射量を計算する。

(4)直達日射, 天空日射，および(1)で求めたキャビティ 表面から反射する日射量からキャビティ内の人体に 入射する日射量を計算する。

(5)大気放射と(3)で求めたキャビティ表面から射出する 長波長放射量から人体に入射する長波長の放射量を 計算する。

(6)人体周りの対流熱伝達率を(2)で求めたキャビティ内 の気流分布から計算する。

(7)キャビティ内の気温と湿度, そして(4), (5)で求めた 放射量を既知として人体の熱収支計算を行い，人体 のぬれ面積率と皮ふ表面温度を計算する。

（8)机面積率と皮了表面温度から新有効温度を計算す る。人体の熱平衡が保てない場合には，熱負荷を計 算し，キャビティ内の熱環境状態を推定する。 以上の手順によってキャビティ内の熱環境状態を推定 し，これらがキャビティの方位や表面の材質によってよ゙ のように変化するか，またキャビティ内ではどのような 物理量が人体の熱収支に大きく関与するか, 人体の熱平 衡はどのような作用で保たれているかを調べる。

キャビティ表面での長波長放射は相互反射を考慮し， 表面熱流は乱流モデルの計算結果から推測した対流熱伝 達率を用いて計算した ${ }^{10)}$ 。

人体の熱収支の計算に関しては，図一 3 に示すような 2 つの近似を行っている。1つは，人体を人体の表面積 と身長が等しくなるような円柱にモデル化し，長波長放 射, 短波長放射の計算を行う。もう 1 つは，皮了表面の 露出部は無いと見做し，人体はすべて衣服によって被わ れていると仮定する。前者の仮定では，対流伝熱面積と 放射伝熱面積を同一視するという難があるが，問題をで きるだけ単純化させるためにそれ梑上の詳細な取り扱

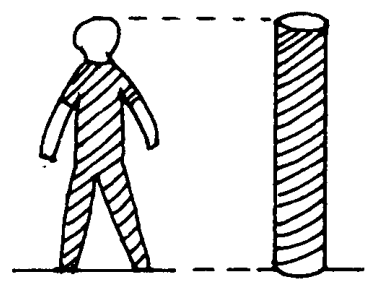

人体表面積と身長が等しい円柱にモテル化 皮露出部は無しと近似

図一3人体のモデル化

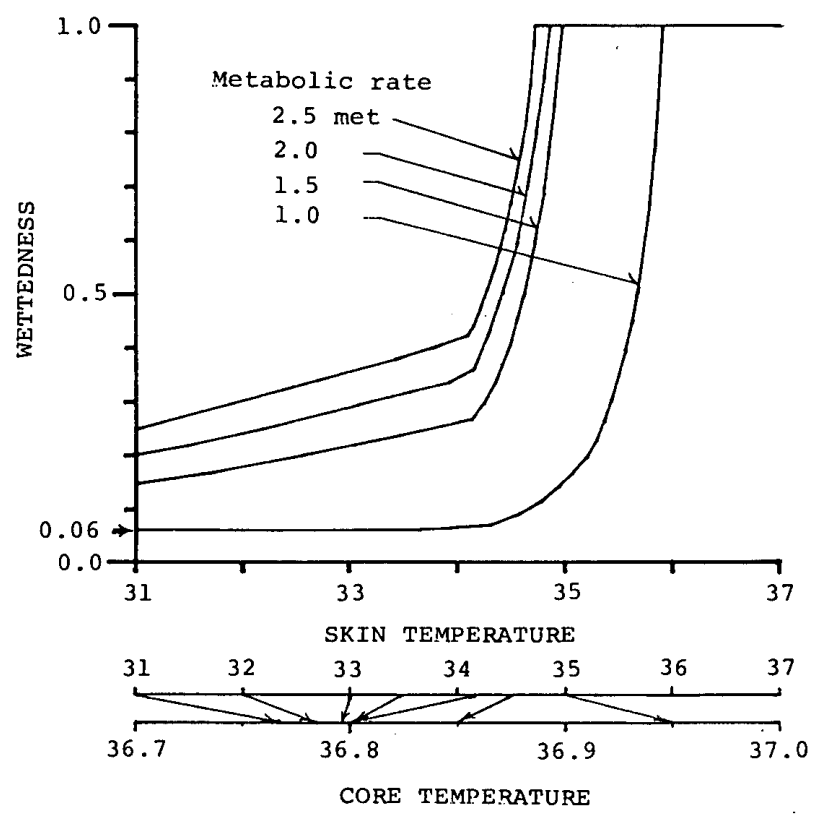

図一4 ぬれ面積率と皮周表面温度

いを避けた。

人体の熱収支の計算法は Terjung ${ }^{6)}$ の方法に従った。 ただし，ぬれ面積率と皮ふ表面温度の関係は Gagge ${ }^{11} の$ プログラムから計算した。この関係を図一4に示す。

人体の対流熱伝達率は次式を用いた。

$$
h_{c}=8.64 \cdot V^{0.531} \quad\left(\mathrm{~W} / \mathrm{m}^{2} \mathrm{~K}\right)
$$

ここで， $h_{\mathrm{c}}$ は対流熱伝達率，Vは風速 $(\mathrm{m} / \mathrm{s})$ である。 人体表面積は体重と身長から次式で決定した。

$$
A D U=0.202 \cdot W_{g}^{0.425} \cdot H^{0.725}
$$

ここで，ADU は人体表面積 $\left(\mathrm{m}^{2}\right), W_{8}$ は体重 $(\mathrm{kg})$, $H$ は身長 $(\mathrm{m})$ である。

人体の熱収支が平衡を保てない場合，ぬれ面積率を 1 とし, 熱平衡が保ち得る最大の皮ふ表面温を与え，次式 で熱負荷を定義した。

熱負荷 $=$ 人体に蓄熱される熱量／人体熱容量 熱負荷の意味は，一定体温を保てなくなるほよ゙の過大の 熱量が人体に作用することを表すが，それを数值で示す ために上式の表現を用いた。すなわち，式で表された熱 負荷は, 人体の熱平衡が保てない状態での, 単位時間当 たりの体温上昇を表す。

表一1 固定したキャビティの条件

FIXED CONDITION

\begin{tabular}{|l|l|l|}
\hline $\begin{array}{l}\text { geometry of } \\
\text { building }\end{array}$ & building height & $16 \mathrm{~m}$ \\
\cline { 2 - 3 } & distance between walls & $16 \mathrm{~m}$ \\
\cline { 2 - 3 } & wall thickness & $12 \mathrm{~cm}$ \\
\hline $\begin{array}{l}\text { physical } \\
\text { properties } \\
\text { of wall } \\
\text { (concrete) }\end{array}$ & short-wave absorptivity & 0.7 \\
\cline { 2 - 3 } & emissivity & 0.9 \\
\cline { 2 - 3 } & thermal conductivity & $1.5 \mathrm{~W} / \mathrm{mK}$ \\
\cline { 2 - 3 } room & $\begin{array}{l}\text { indoor overall heat } \\
\text { transer coefficient }\end{array}$ & $9.3 \mathrm{~W} / \mathrm{sq} . \mathrm{mk}$ \\
\cline { 2 - 3 } & room temperature & $27 \mathrm{deg}$ \\
\hline \multirow{3}{*}{ ground } & $\begin{array}{l}\text { temperature } \\
\text { (So cm under ground) }\end{array}$ & $26.5 \mathrm{deg}$ \\
\hline \multirow{2}{*}{ roughness } & rooftop & $\mathrm{cm}$ \\
\cline { 2 - 3 } & cavity surface & $1 \mathrm{~cm}$ \\
\hline
\end{tabular}


言一2 変化させたキャビティのパラメータ PARAMETER

\begin{tabular}{|c|c|c|c|c|}
\hline $\begin{array}{l}\text { ground } \\
\text { material }\end{array}$ & $\begin{array}{l}\text { short-wave } \\
\text { absorptivity }\end{array}$ & emissivity & \begin{tabular}{|l|} 
thermal \\
conductivity
\end{tabular} & $\begin{array}{l}\text { thermal } \\
\text { diffusivity }\end{array}$ \\
\hline $\begin{array}{l}\text { concrete } \\
\text { dry soil } \\
\text { wet soil }\end{array}$ & $\begin{array}{l}0.7 \\
0.7 \\
0.9\end{array}$ & $\begin{array}{l}0.9 \\
0.9 \\
0.9\end{array}$ & $\begin{array}{l}1.5 \text { W/K } \\
0.53 \\
0.65\end{array}$ & $\begin{array}{l}2.8 E-399 . \mathrm{m} / \mathrm{h} \\
1.2 \mathrm{E}-3 \\
1.4 \mathrm{E}-3\end{array}$ \\
\hline
\end{tabular}

\begin{tabular}{|l|l|}
\hline direction & east to west \\
\cline { 2 - 2 } of cavity & north to south \\
\hline
\end{tabular}

䨿一3 人体に関する条件

CONDITION OF HUMAN BODY

\begin{tabular}{|l|l|}
\hline merabolic rate & 1.5 met \\
\hline CLO value & $0.43 \mathrm{clo}$ \\
\hline emissivity of clothes & 1.0 \\
\hline short-wave absorptivity & \\
of clothes & 0.6 \\
\hline weight of human body & $65 \mathrm{~kg}$ \\
\hline height of human body & $1.7 \mathrm{~m}$ \\
\hline
\end{tabular}

祘一4 気象デー夕（太陽高度と方位角）

SOLAR ALTITUDE AND AZIMUTH

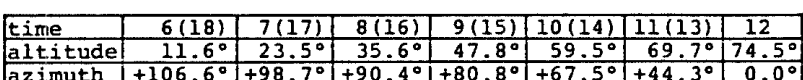

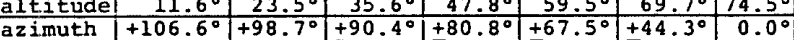
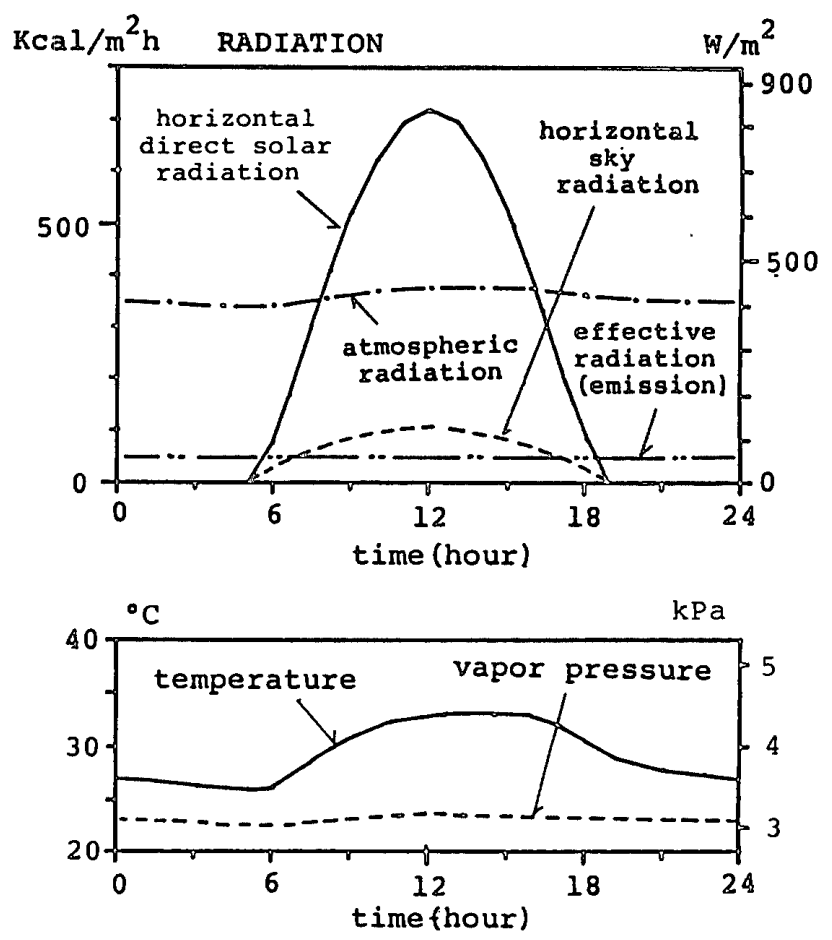

UPPER WIND VELOCITY AND DIRECTION

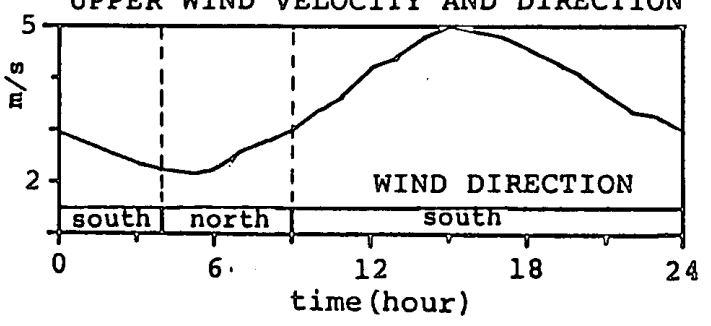

図一5計算に用いた気象データ

\section{3. 路橗と洘察}

計算に用いた条件を表一 1 から表一 3 に示す。表一 1

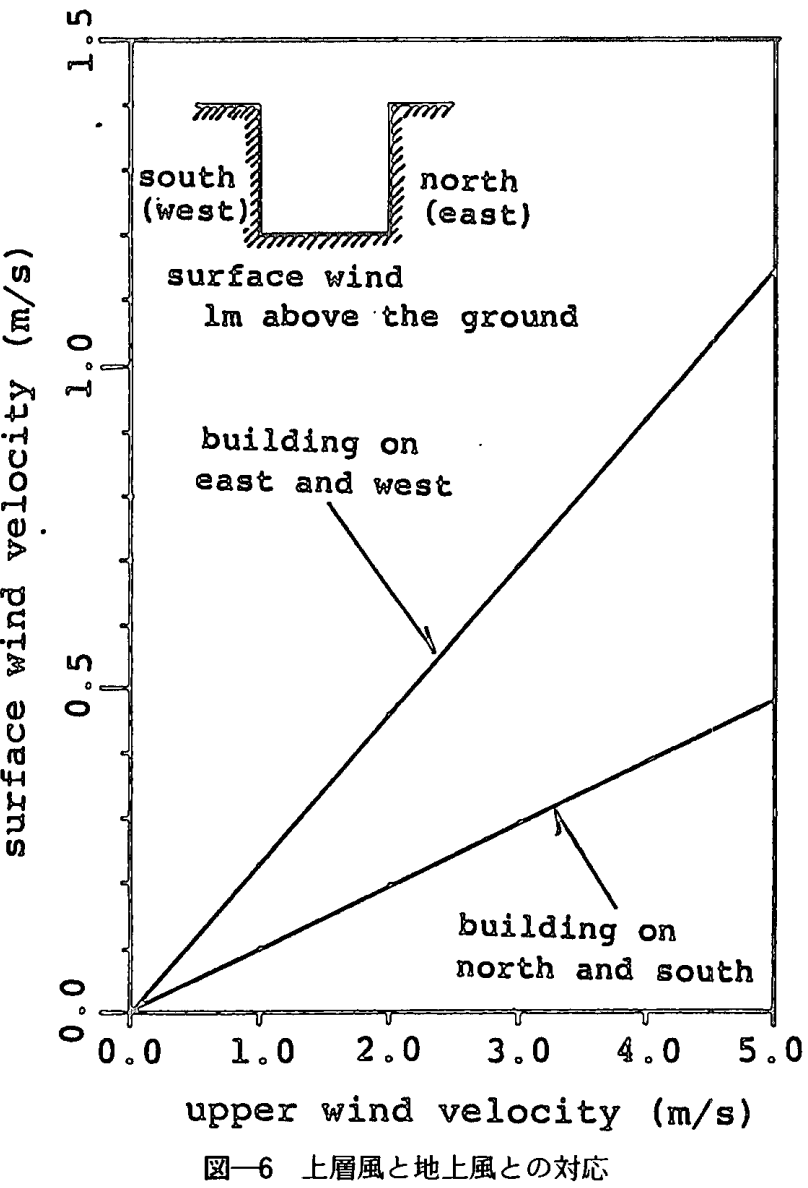

はキャビティに関して固定した条件を示す。表一 2 は変 化させたパラメータ，表一3は人体に関する条件を示す。 今回は表一 2 に示すパラメータに加え，参考のために実 測加ら得られた地上風速と屋上風速の関係（地上風速= $(2 / 3) \cdot$ 屋上風) $)^{12)}$ から得られた結果も示す (図一12 以 降の図中の (E) の場合)。

計算に用いた気象データを表一 4 と図一 5 に示す。気 象デー夕は東京の夏期冷房外気条件である。ただし風速 は 8 月の東京の時刻別平均風速, 風向は 8 月の時刻別最 多風向を示す。風向は北之南の 2 方向のみ。

\section{1 上層風と地上風の関係}

計算から得られた地上風と上層風の関係を図一 6 に示 す。キャビティの壁面が北と南のとき，上層風の風向は 楎に直角であり，壁面が東と西のとき，風向は棟に平行 になっている。どちらの場合も上層風と地上風の関係は 直線になっている。また，上層風が棟に直角に吹くか平 行に吹くかによって, 地上での風速が変化し, 前者のほ うが減衰率が小さい。すなわち，上層風の風向が棟に直 角のとき，地上風と上層風の比例定数は 0.1 , 風向が显 に平行のとき比例定数は 0.2 程度に成っている。地上風 速は上層風の風向の変化によって, かなり変化し得るこ とが推測される。

図一7 は地上風の時間変化を示す。壁面が東と西にあ るキャビティでは，壁面が北と南のキャビティに比べ, 


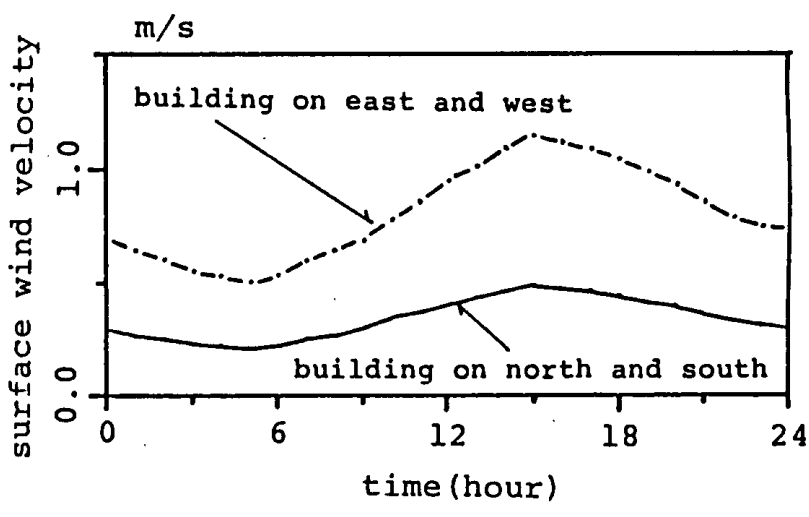

surface wind : Im above ground 図一7 地上風の時間変化

地上風は一日を通して常に 2 倍程度大きくなっている。 これは図一6で示したように，上層風の風向が地上風の 風速に大きな影響を与えるためである。

3.2 人体に入射する放射量

図一8にキャビティ表面から人体に入射する放射量を
示す。地面の材質はコンクリート，キャビティ壁面は南 と北, 人体の位置はキャビティ中央のときの計算結果で ある。図一8（a）は短波長成分，（b）は長波長成分を 示す。長波長成分は外気温度基準とした。これは入射す る放射量から外気温度で射出する放射量を引いたもので ある。長波短波ともに地面からの放射量が大きい。この 原因は人体から地面を見る形態係数が大きいことに因 る。キャビティ中央では日中ほとんよ゙日が当たっており， 地面からの日射の反射の有ることと，地面が壁面に比べ 高温になっていることも地面からの放射量が大きい事の 一因になっている。

図一9に地面材質の人体に入射する放射量への影響に ついて示す。キャビティ壁面は南と北にあり, 人体はキャ ビティ中央にある。図一9（a）は拡散短波長成分を示す。 直達日射は含めていない。コンクリートと乾いた土は同 じアルベード，アスファルトと湿った土も同じアルベー ドである。人体に入射する拡散短波長放射は地面材質に よって大きくかわる。図一9（b）は人体に入射する放

INCIDENT RADIATION FROM WALL AND GROUND bullding on north and south icenter point

short wave diffuse readiation

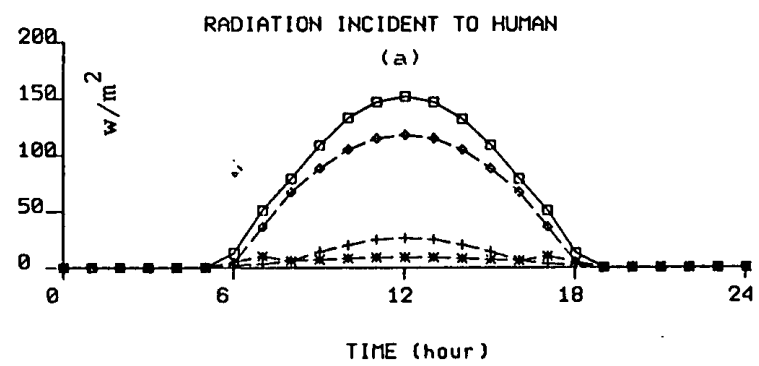

Shart-wave Radlation Incldent to Human : (CONCRETE) Diffuga radlation : fexcluding diract solar radiattlon)
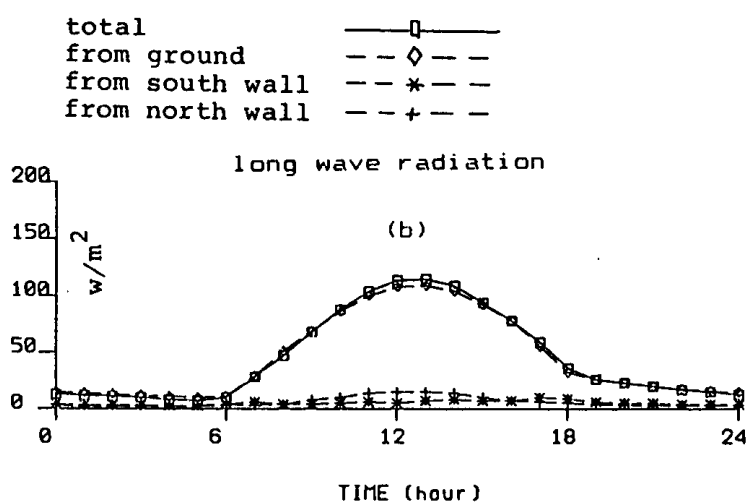

Long-wave Radiallon Incldent to Human : (CONCRETE) (based on outdoor temperature)

図一8 キャビティ壁面および地面から人体に入射する放射量

RADIATION INCIDENT TO HUMAN bullding on north and south

SHORT WAVE DIFFUSE RADIATION

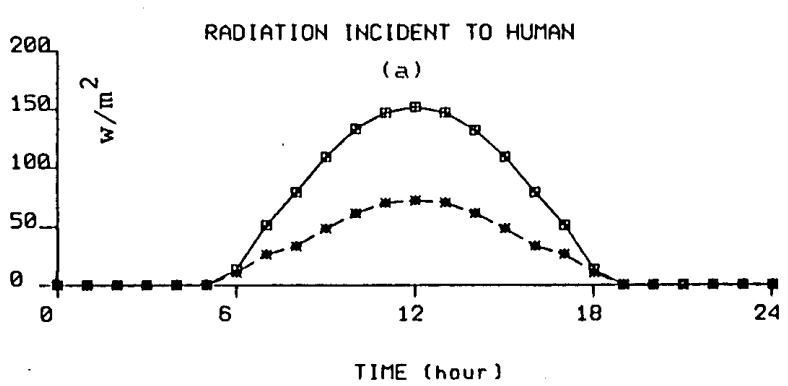

Short-wave Radlation incldent to Human Diffuse Radlation (excluding direct solar radiation) (centur polnt) : bullding on south and north

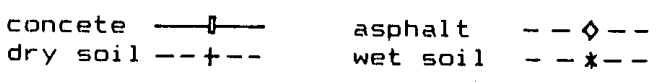
LONG WAVE RADIATION

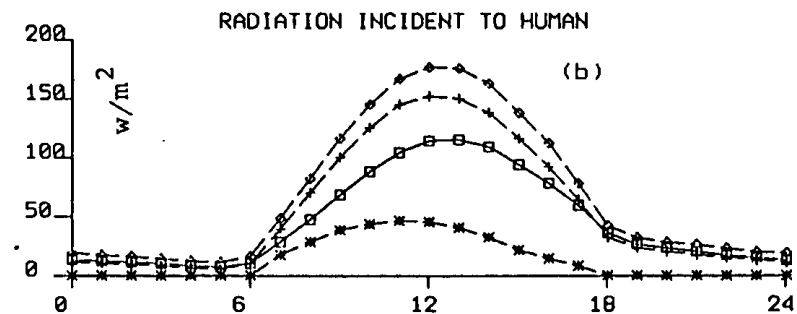

TIME (hour)

Long-wave Radlation Incldent to Human

(based on outdoor temperature)

(center polnt) : bullding on south and north 
射量を外気温基準で表したもの，換言すれば有効放射場 を示す。(a) の場合とは逆に, アスファルトの場合, 入 射する放射量が大きくなっている。これはアスファルト が最も高温になることが原因である。同じアルベードの 湿った土では水分蒸発によって熱を放出するため, 地面 温度が上昇せず, 結果として四種類の材質の中で最も小 さい長波長放射量となっている。

人体に入射する長波長成分を減少させるには地面表面 温度を低下させることが効果的であり，壁面温度の影響 はそれほど大きくはない。

\section{3 人体に吸収される放射量}

人体に吸収される放射量を図一10に示す。この量は 外気温度基準であり,人体が正味吸収する放射量である。 符号が負のときは放出側に転じることになる。図に示さ れている記号 (A) から (D) の説明は表一5に示して ある。(A) は北と南に壁をもつキャビティで，人体が 地面中央にあるときの吸収される放射量の時間変化を示 す。(B) は人体に直接当る直達日射を除いた放射量を 示す。天空日射やキャビティ表面から反射する拡散日射 は含んでいる。(A) と（B）の比較から直達日射量の 有無が人体に吸収される放射量に大きく影響することが
表一5 各図の計算条件

\begin{tabular}{|c|c|c|c|c|c|}
\hline 琼号 & 建物方位 & 人体の位置 & 面荤日射 & 国速 & 比皎の目的 \\
\hline (A) & 南·北壁 & 中央 & 有 & 計算 & 基䧱 \\
\hline (B) & 南·北壁 & 中央 & 無 & 計算 & 直䔔日射の有無 \\
\hline (C) & 南: 北壁 & 南壁から2。 & 有 & 計算 & 日陰の効果 \\
\hline (D) & 舀·西壁 & 中央 & 有 & 計算 & 建物方位の遠い \\
\hline (E) & 南·北壁 & 中央 & 有 & 実测 & 風の读倨 \\
\hline
\end{tabular}

わかる。(C) は人体が南壁から $2 \mathrm{~m}$ の位置にあるとき の人体が吸収する放射量である。この位置は一日を通じ て日陰になる時間が長い。(C) の場合, 吸収される放 射量は (A) に比べてひじょうに小さい。この原因は, 直達日射が当たらないこと, 日陰のため足下近くの地表 面温度が低いこと，そして足下近くからの日射の反射が ないためである。（D）はキャビティ壁面が東と西の場 合の吸収される放射量を示す。人体の位置は地面中央で ある。(A) に比べ,グラフのパターンが異なっている のは，キャビティ方位の違いによって直射日光の当たり 方が異なってくるためである。ピーク值の低下は，キャ ビティ方位の違いにより対流熱伝達率が大きくなり, 地 表面温度の低下をもたらしたことが主な原因となってい

RADIATION ABSORBED BY HUMAN (bosed on out-door temperature)

bullding on north and south
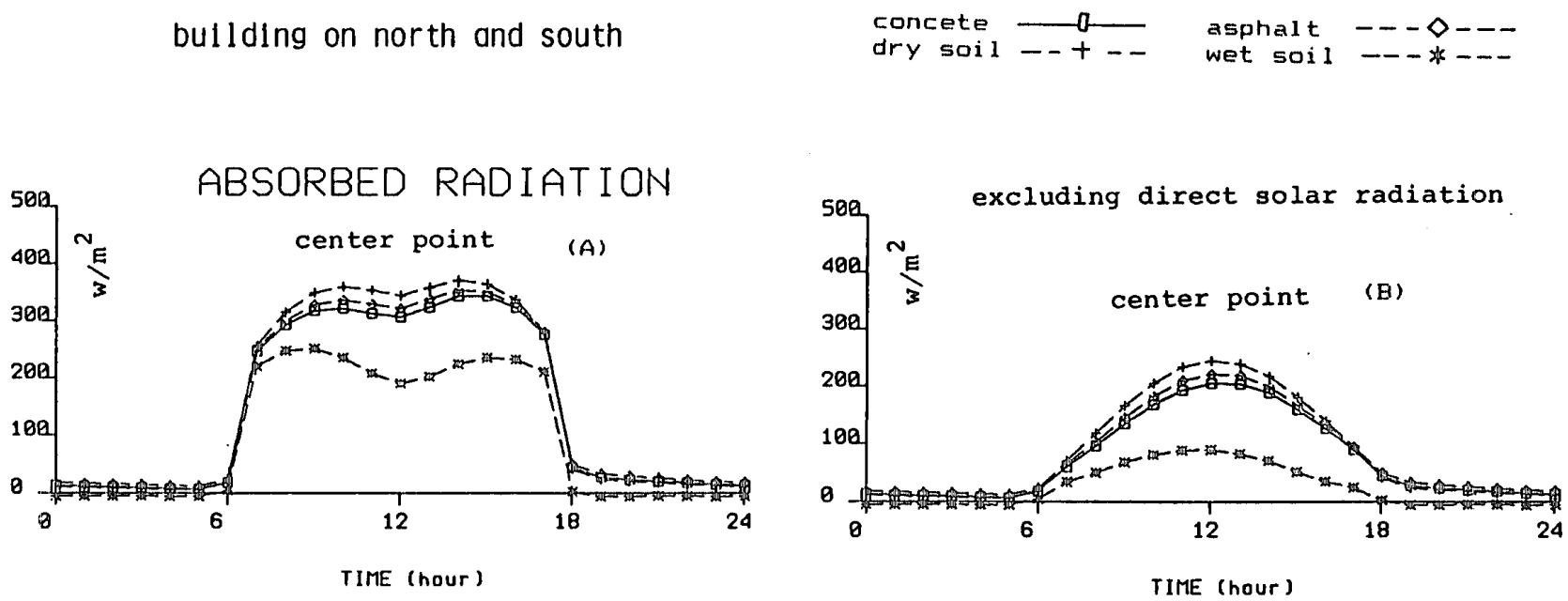

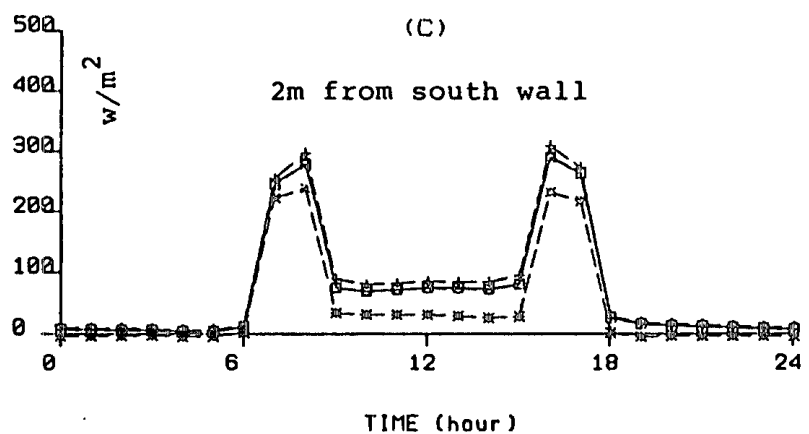

including direct solar radiation

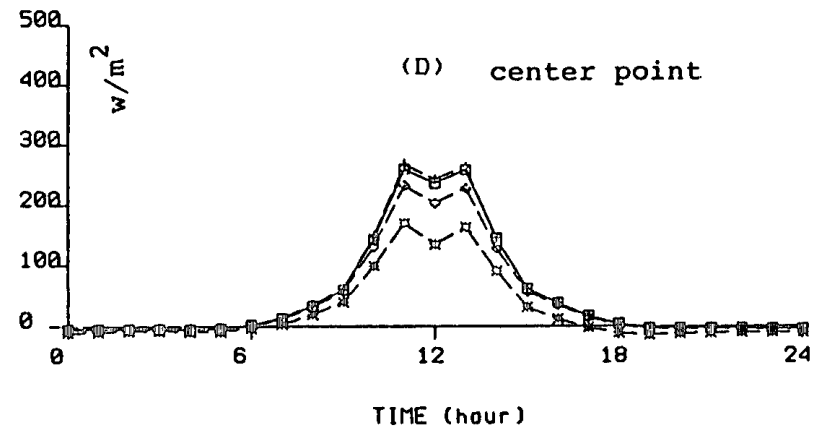

building on east and west including direct solar radiation

図一10人体によって吸収される放射量 
る。(A) から (D) いずれの場合も，湿った土を除い て吸収される放射量の地面材質の違いによる効果は少な い。アスファルトは乾いた土やコンクリートに比へ，短 波長成分として人体に吸収される量は少ないが, その分, 地表面を高温にし，長波長放射として人体に吸収される 量を大きくしている。結果として吸収される放射量には 差が出てこなくなっている。湿った土はアルベードが小 さいことと水分蒸発により表面温が低く，他の地面材料 に比へ，人体に吸収される放射量を小さくしている。

\section{4 作用温度}

図一11に作用温度を示す。破線は外気温度を示す。 破線よりも上側が放射の効果を示す。夜間に作用温度が 外気温度よりも低下するのは，放射の収支に関して人体 が熱を放出していることを表す。(A) から (D) の記 号は図一10 と同様に，表一5に説明してある。

（A）から (D) のいずれの場合においても，放射の 効果が大きく, キャビティ内の気温変動は作用温度には それほど影響しない。人体の熱収支計算においては,キャ ビティ内の気温分布は考虑する必要がないことが推定さ れる。(A) の場合，放射の効果が非常に大きい。(B) は直達日射を除いた拡散日射と長波長放射による作用温 度を示す。直射成分を除くと，作用温度のかなりの低下 が見られるが，拡散日射や長波長放射による寄与も大き

\section{OPERATIVE TEMPERATURE}

(TO)

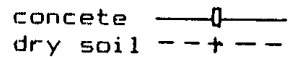

TO

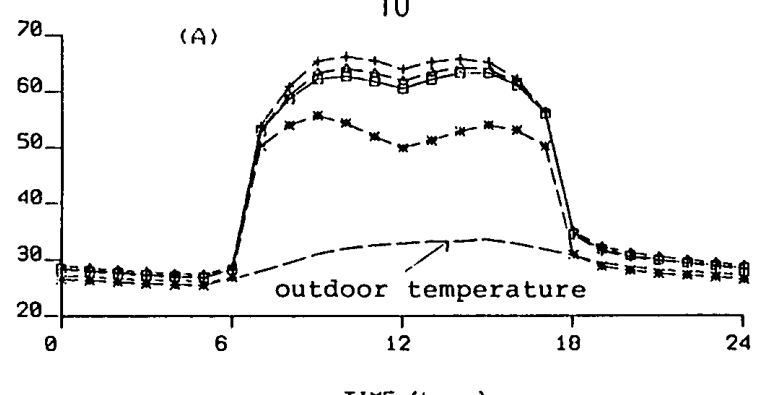

TIME (hour)

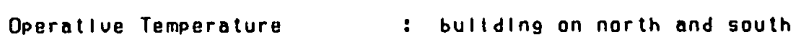
(center polnt) : Including diract solar radiation

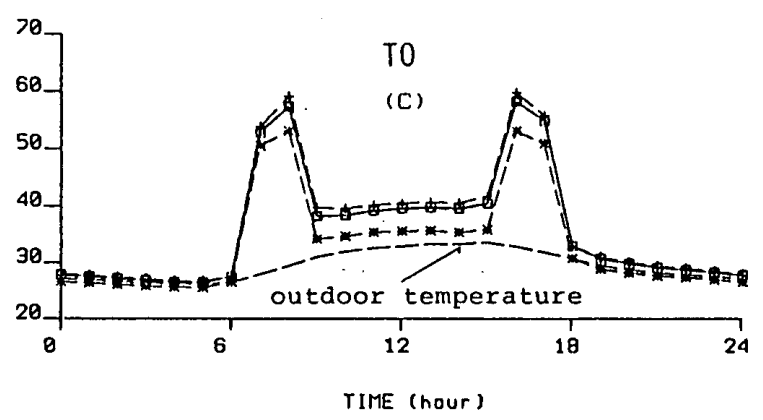

Operallue Temperature : bullding on north and south (2m from south wall) : Including direct solar radiallon
い。（C）は日陰部分での作用温度を示す。(A) に比べ, 日陰部分では作用温度が極端に低下しているのがわか る。また直射成分を除いた（B）に比べても作用温度は 低い。（D）はキャビティ壁面が東と西にある場合の作 用温度を示す。人体の位置は地面中央である。グラフの パターンが $(\mathrm{A})$ と異なっていることとピーク値の低下 の原因については，3.3の人体に吸収される放射量の所 で述べた。

地面材質の違いによる効果に対しては，“湿った土の場 合を除き，他の材料については差がなかった。

\section{5 新有効温度 $\left(\mathrm{ET}^{*}\right)$}

新有効温度のグラフを図一 12 に示す。人体の熱収支 計算において熱平衡が保てない状態が生じたが，ぬれ面 積率を 1 として皮ふ表面温度を上昇させ，計算上熱平衡 を保たせて，皮了表面温度を計算し，新有効温度を求め ている。熱平衡が保てない場合には，別途，熱負荷を計 算している。新有効温度および熱負荷は定常状態を前提 としているため，実際の人体の熱収支状態を示すもので はないが，キャビティの持つ物理的な熱環境状態を示す ものと考えられる。

（A）は壁面が北と南にあるキャビティで，人体は地 面中央にある状態での $\mathrm{ET}{ }^{*}$ の時間的変化を示す。直射 日光が人体に当たると同時に $\mathrm{ET}$ *は急激に上昇する。 asphalt $-\Delta--$
wet soil $--*--$

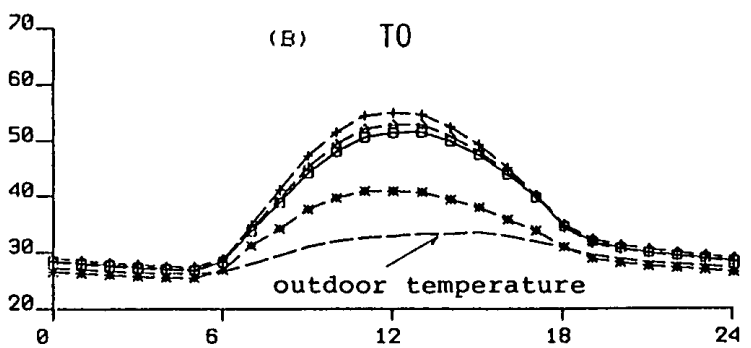

TIME (hour)

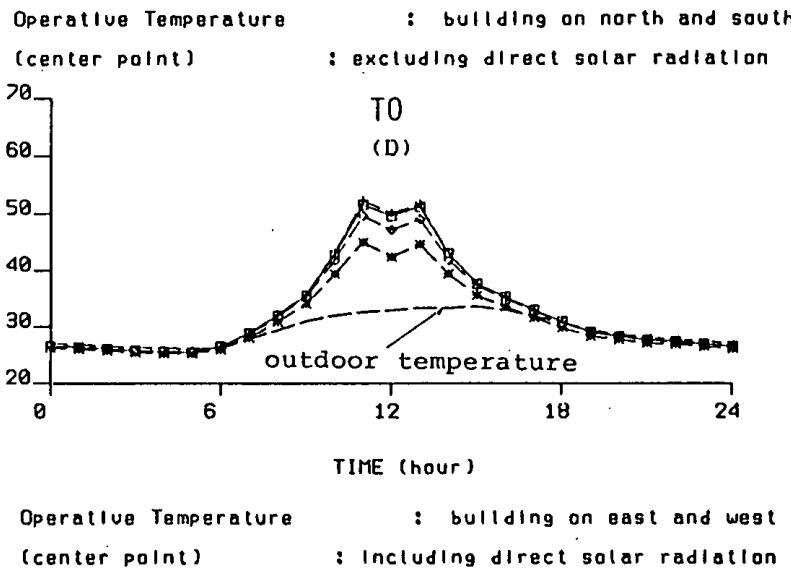

図一11 作用温度 
キャビティ中央では，この状態が直射日光が当たってい る間続き，その後急に低下する。日中での $E T^{*}$ の上昇 は人体に直射日光が当たること，人体に入射する拡散日 射と長波長放射が大きいことが原因となっているが，そ の他にも地上風の効果がある。地上風の大小が人体の熱 伝達率に影響し，これが最大可能蒸発量を増減させ，人 体の発汗量に大きく作用するためである。

(E) のグラフは上層風と地上風との関係を $2 / 3$ とし て計算した結果である。この関係は実測 ${ }^{12)} に よ り$ 得られ たものである。キャビティ内部の風速はすべて，この関 係を用い，キャビティ表面での対流熱伝達率はユルゲス の式から計算している。人体に吸収される放射量は (A) の場合とそれほど差はないが，ET のグラフでは $(\mathrm{A})$ に比べ減少が著しい。これは地上風の増大による発汗の 促進が原因である。

（B）は（A）の状態から人体に直接入射する直達日 射成分を除いたときの $\mathrm{ET}$ の值を示す。(B) の場合は, (A) に比べET の值が小さくなっており, 直達日射の 効果が大きいことを示している。(C) は人体を南壁面 から $2 \mathrm{~m}$ の位置においたときの ET の値を示す。この 位置は日中は日陰になっている。(B) の場合よりも， さらに $\mathrm{ET}{ }^{*}$ の値が減少している。これは直達日射が無 いこと，日陰のため足下近くからの日射の反射が無いこ
と，そして足下近くの地表面温度が低いため，人体に吸 収される放射量が小さくなっているのが原因である。 (D) のキャビティ方位が異るっている場合，(A) に比 ベ, ET*のグラフのパターンが異なっており，またピー ク値も減少している。この原因についても，3.3の人体 に吸収される放射量の所で述べたが，ET"の場合は， それ以外に地上風の違いが発汗に直接影響している。図 一7に示すように地上風速が $(A)$ に比べ約 2 倍になっ ておりこのことが発汗を促進させ，ET"の值を低下 させる原因になっている。

地面材質の効果に関しては，水分蒸発のある湿った土 が他の材質に比べET *低下させる作用が大きい。

\section{6 人体の熱負荷}

人体が熱平衡を保てない状態を熱負荷として図一13 に示す。(A) は基準としたキャビティ配置と人体の位 置での熱負荷を示す。 4 種類の地面材質すべてに対して 熱負荷が生じているが,湿った地面ではその值が小さい。 （E）は上層風と地上風の関係を実測から得られた値を 用いて計算した結果である。この場合には熱負荷が零に なっており，地上風の大小が人体の熱収支に重要な役割 を持つことがわかる。地上風の増大は, 人体の最大可能 蒸発量を増大させ，発汗を促進させる。(B) は $(A)$ の状態から直達日射を除去した場合の熱負荷を示す。日

\section{NEN EFFECTIVE TEMPERATURE (ET⿱中)}
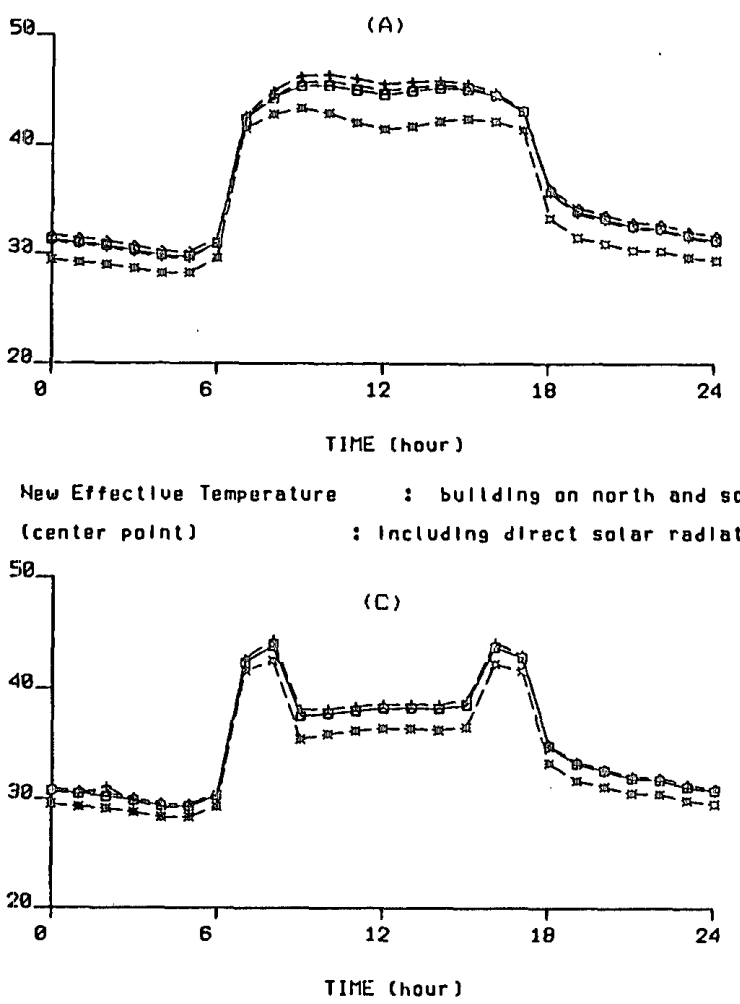

New Effoctlue Temperature : bullding on north and south (2m fram snillh wall) : including dlrect solar radlation
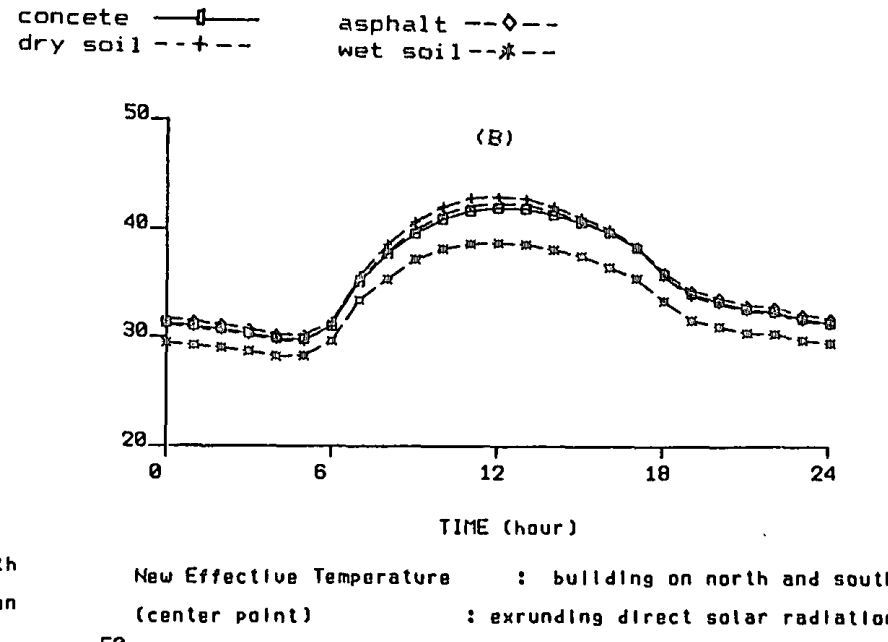
50

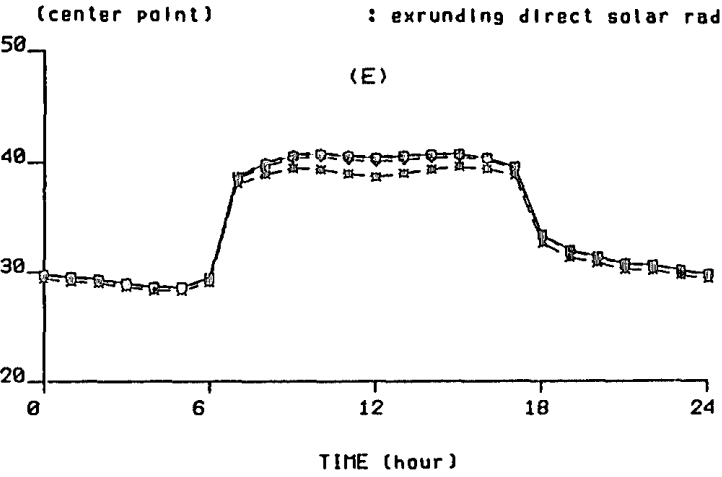

New ET [U=(2/3)*Uroof $]$ : bullding on north and south (center panlt) : Including direct solar radiation 


\section{THERMAL LOAD}

bullding on north and south

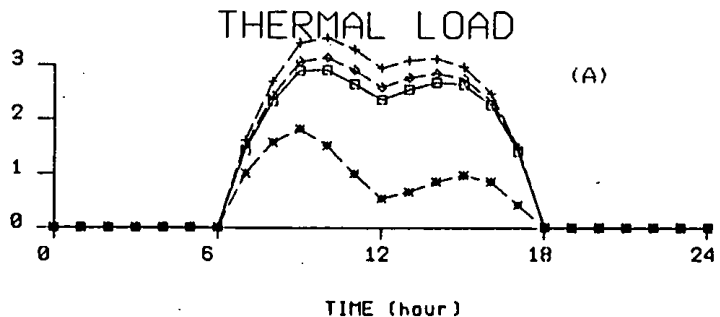

Thermat Load (deg/hour) : bullding on north and south (centerpolnt) : Including direct sotar radiatlon

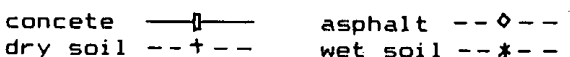

THERMAL LOAD

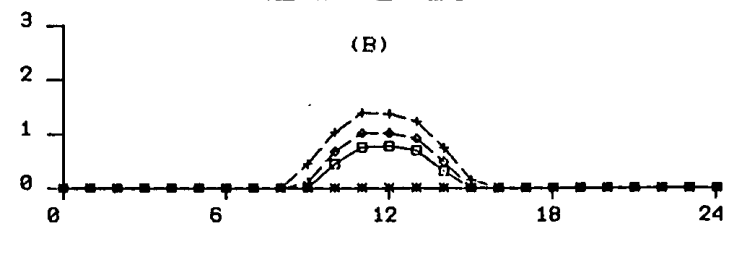

TIME (hour)

Thermal Lood (deghour) : bullding on north and south (center polnt) : excluding direct sotar radiation
THERMAL LOAD

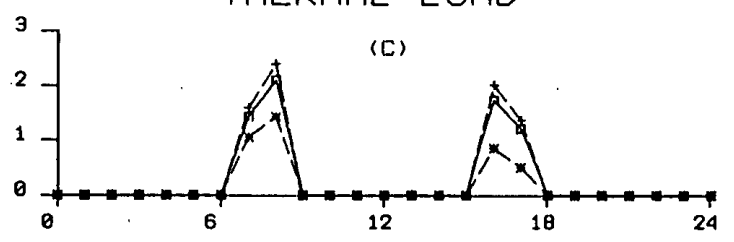

TIME (hour)

Thermal Lood (deghour) : bullding on north and south (2m from south walt) : Including diract solar radlatlon
THERMAL LOAD

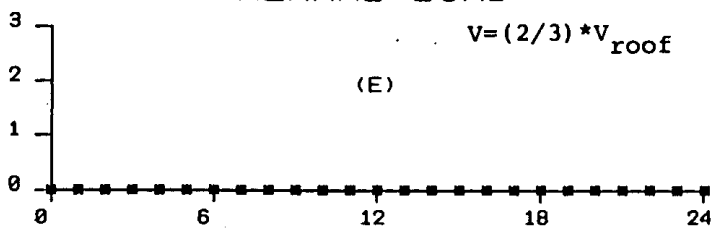

TIME (hour)

Thermal Load (deg/hour) : bullding on north and south (center polnt) : Including direct solar radiatlon

図一13人体の熱負荷

\section{ENERGY BUDGET OF IIUMAN BODY}

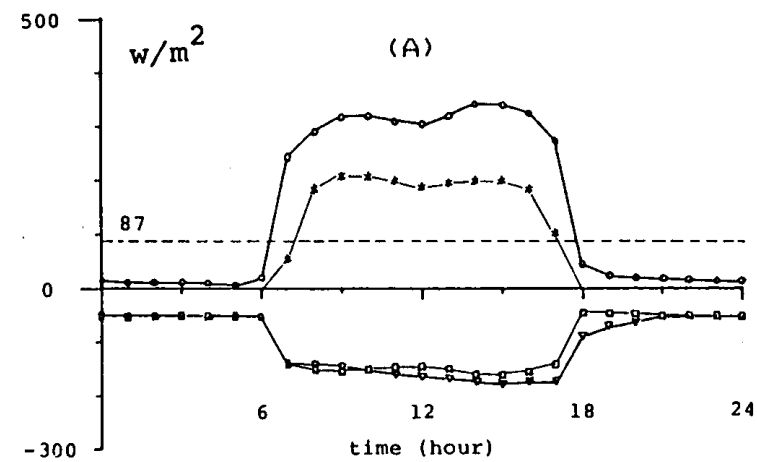

energy budget of human body : concrete

(center point) : building on north and south velocity ; from calculation

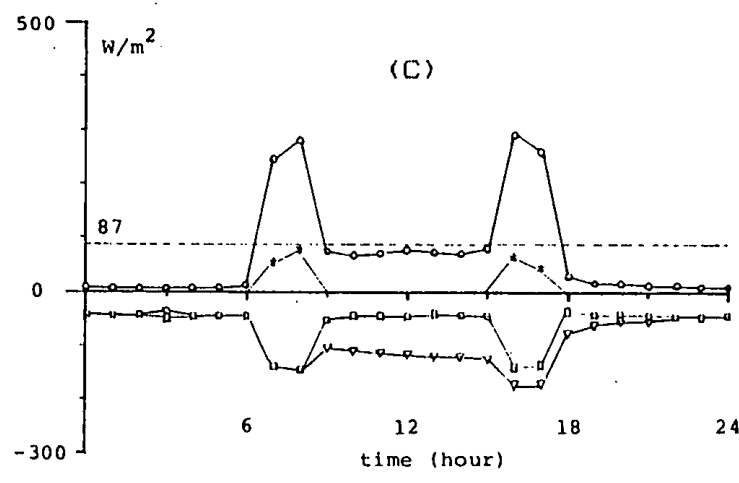

energy budget of human body : concrete

$(2 \mathrm{~m}$ from south wall) : building on north and south velocity ; from calculation
(R) radiation $\longrightarrow$ (S) perspiration

(C) convection - *- (TL) stored energy (M) metabolic rate by human body

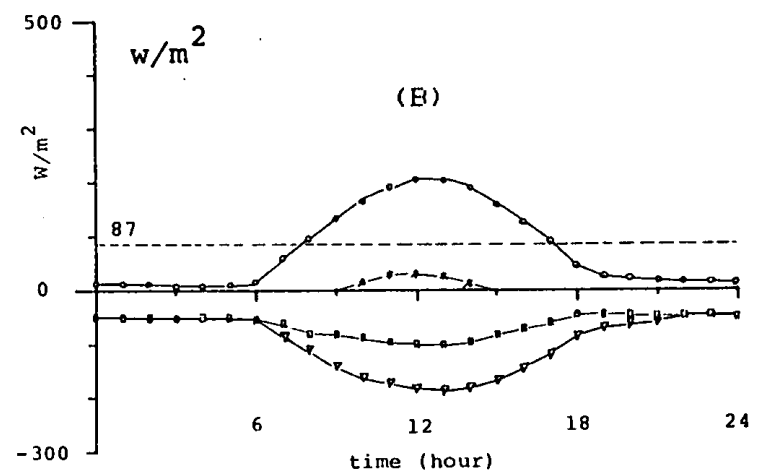

energy budyet of human body : concrete

(ceneter point) : bullding on north and south velocity; form calculation: excluding direct solar radiation

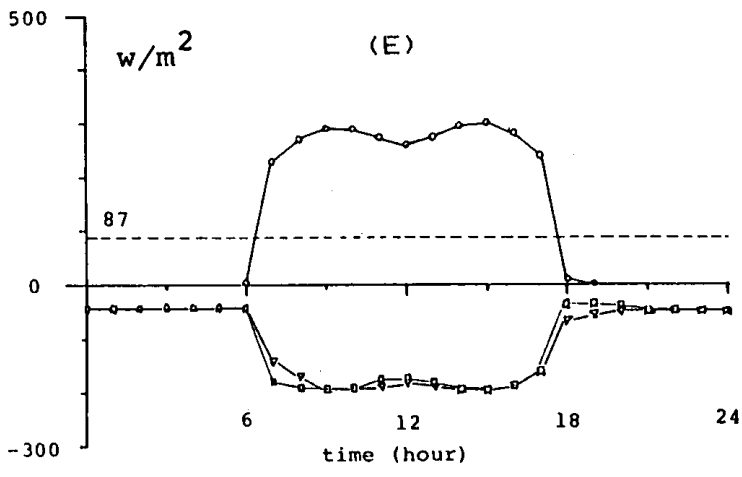

energy budget of human body : concrete (center point) : building on north and south velocity; $v_{\text {surf }}=(2 / 3) \star v_{\text {roof }}$ 
中，数時間熱負荷が生じているが，(A) に比べその値 は減少している。(D) は (A) の場合と，キャビティ の方位が異なる場合のものであるが，この場合，熱負荷 は囹になっている。この場合も地上風の増大の効果が強 い。(グラフは省略した。)

\section{7 人体の熱収支}

前節まではキャビティの物理的な熱環境を形成する気 流や放射量, そしてこれらの物理量から生じる人体の温 熱生理指標について検討した。この節では，人体がどの ようにして熱収支を保っているか，どのようなメカニズ ムで人体は熱を放出しているかを調べる。

図一14 は人体の熱収支の詳細について示したもので ある。正方向が流入量, 負方向が放出量を示す。キャビ ティ内では日中は放射量と対流熱伝達量の和は正，すな わち，流入側になっている。この流入する顕熱量と代謝 量を発汗によって放出している。夜間は代謝量を対流と 発汗によって放出している。㭔吸による熱放散は無視し 得るほど小さい。

（A）の場合は，吸収する放射量が大きく，地上風の 風速が小さいため，人体への蓄熱量が大きい。(E) の 場合は，放射量は（A) どほぼ同じにもかかわらず，人 体への蓄熱が無くなっている。これは地上風が大きく発 汗と対流熱伝達を増大させたためである。（B）は人体 に直接入射する直達日射を除いた場合であるが，人体へ の蓄熱が少し生じている。これは（E) の場合と対照的 である。この原因は地上風の風速の差に因る。

（C）は日陰部分での人体の熱収支の状態を示してい る。日陰部分では人体が吸収する放射量が極端に小さい ため，地上風が弱くても十分に熱平衡を保つことができ ることをこの図は示している。

\section{4. 結 諭}

湢が $16 \mathrm{~m}$, 高さと㽬の比が 1 の典型的な都市キャビ ティ空間について，地上にある人体を円筒で置き換える という簡単な近似化モデルで，夏の気象条件で数值計算 を行った結果，人体表面の熱収支に関しては，

(1)人体に直接入射する直達日射の有無が人体の熱収支 に大きく作用する。

(2)地上風の大小は，発汗を増減させるため，人体の熱 収支への寄与が大きい。

(3)キャビティ内部では，日中は体温上昇をきたすほよ゙ の熱環境に成っている。

(4)地面の影響が大きい。これは人間の立っている足下 近くの形態係数に因る。

(5人体が吸収する放射量は，拡散日射量と長波長放射 量とは同程度である。
(6)日陰部分の効果が大きい。

(7)地面材質の違いによる効果に対しては，湿った土の 効果が大きいが，他の材質については差がない。 以上の点が結論として挙げられる。

本研究は, 昭和 59 年度・文部省科学研究費補助金・ エネルギー特別研究・課題番号 59045083 によった。

\section{参考文献}

1) Fuggle, R.F \& Oke, T.R. : Long-wave radiative flux divergence and nocturnal cooling of the urban atomosphere I : above roof-level, Boundary Layer Meteorology, $10,113-120,1976$

2) Nunez, M. \& Oke, T.R. : Long-wave radiative flux divergence and nocturnal cooling of the urban atomos. phere II : within an urban canyon, Boundary-Layer Meteorology, 10, 121-135, 1976

3) Nunez, M. \& Oke, T.R. : The energy balance of an urban canyon, J. Appl. Meteorol., 16, 11-19, 1977

4) Terjung, W.H. \& O'rourke, P. A. : Influences of physical structures on urban energy budgets, Boundary Layer Meteorology, 19, 421-439, 1980

5) Terjung, W.H. \& O'rourke, P.A. : Simulating the causal elements of urban heat islands, Boundary Layer Meteorology, 19, 93-118, 1980

6) Burt, J.E., O'rourke, P.A. \& Terjung, W. H. : The relative influence of urban climates on outdoor human energy budgets and skin temperature I. modeling considerations, Int. J. Biometeor., 26, 3-23, 1982

7) Burt, J.E., O'rourke, P.A. \& Terjung, W. H. : The relative influence of urban climates on outdoor human energy budgets and skin temperature II. man in an urban environment, Int. J. Biometeor., 26, 25-35, 1982

8）内藤和夫, 水野稔, 漆崎 昇：都市気温形成因子とし てのアーバンキャニオンの重要性, 空気調和・衛生工学 会諭文集，第 22 号，41-49，1983

9） 中村泰人, 平岡久司, 西村浩一, 吉田篤正: 二次元長方 形キャビティ空間の熱環境制御に関する実鈳，日本建築 学会近畿支部研究報告集, 第 24 号〈計画系〉, 77-80, 1984

10）中村泰人, 平岡久司, 西村浩一, 吉田篤正 : 二次元長方 形キャビティ空間の熱環境制御に関する数值解析，日本 建築学会近畿支部研究報告集, 第 24 号〈計画系>, 81-84, 1984

11) Gagge, A.P., Stolwijk, J. A. \& Nishi, Y. : An effective temperature scale based on a simple model of human physiological regulatory response, ASHRAE Trans., 77, 247-262, 1971

12）中村泰人，平岡久司，西村浩一，永岡孝一：市街地空間 の地上における気流性状, 日本建築学会近畿支部研究報 告集，第 25 号<計画系>，9-12，1985 


\section{SYNOPSIS}

UDC : $697.13: 697.11: 711.4 .01$

\section{NUMERICAL ANALYSIS OF THERMAL LOAD ON A HUMAN MODEL IN AN URBAN CANYON OF TWO-DIMENSIONAL RECTANGULAR CAVITY TYPE}

by Dr. Yasuto NaKamuRA, Assoc. Prof. of Kyoto Univ. and HISASHI HIRAOKA, Instructor of Kyoto Univ., Members of A.I. J.

Effects of thermal environment on a human model at the ground in an urban canyon of the two-dimensional rectangular cavity type were calculated. The purpose of the analysis was to make clear the thermal effect of environment on a human body in the urban canyon. Accordingly environmental conditions were varied; which were ground material, presence of direct solar radiation, presence of sun shade, building orientation and strength of wind velocity. A human model was assumed as a cylinder with the same height and surface area as the human. As to the environmental effects on the human model the operative temperature $\mathrm{TO}$, the new effective temperature $\mathrm{ET}^{*}$ and the thermal load were estimated.

The conclusions are as follows : (1) Existing or not of direct solar radiation incident on a human model acts strongly among energy budget of human surface. (2) Wind velocity at the ground controls perspiration on the human, then its contribution in the energy budget is striking. ( 3 ) Thermal environment in the cavity in the daytime is so severe as to make ascend body temperature. (4) The influence of the ground surface to the energy budget is remarkable, which depends on large view angle to the ground. (5) Radiant energy absorbed by a human model is comparable in both of diffuse solar radiation and long wave radiation. (6) The effect of wet soil on modifing the thermal environment to a human model is distinguished, but the other is not different. 